\title{
How Important is Medical Ethics? Descriptive Cross-Sectional Survey among Medical Students of Karachi
}

\author{
Zaeema Ahmer $^{1 *}$, Rameen Fatima ${ }^{2}$, Roheen Sohaira ${ }^{3}$, Maham Fatima ${ }^{2}$
}

\author{
${ }^{1}$ APPNA Institute of Public Health, Jinnah Sindh Medical University, Karachi, PAKISTAN \\ ${ }^{2}$ Jinnah Sindh Medical University, Karachi, PAKISTAN \\ ${ }^{3}$ Jinnah Postgraduate Medical Centre, Karachi, PAKISTAN \\ *Corresponding Author: zaeema.ahmer@jsmu.edu.pk
}

Citation: Ahmer, Z., Fatima, R., Sohaira, R. and Fatima, M. (2021). How Important is Medical Ethics? Descriptive Cross-Sectional Survey among Medical Students of Karachi. European Journal of Environment and Public Health, 5(2), em0083. https://doi.org/10.21601/ejeph/11058

ARTICLE INFO

Received: 17 Feb. 2021

Accepted: 17 May 2021

\begin{abstract}
Introduction: Healthcare ethics is of prime importance and medical students should learn to incorporate it in their everyday practices. Our study aimed to assess and compare the knowledge of medical ethics among students enrolled in a government and a private medical college of Karachi, Pakistan.

Methods: A cross-sectional study was conducted from November-December 2019 among 380 medical students who were recruited via convenience sampling after getting their informed consent. A pre-tested, selfadministered structured questionnaire was used to assess knowledge. Data was analyzed by Statistical Package of Social Sciences version 22.

Results: Majority, 323 (85\%) regarded medical ethics as important while 138 (36.3\%) had acquired their knowledge from different workshops. Almost half, 187 (49.2\%) had knowledge regarding Hippocratic Oath. When asked regarding ethical scenarios, 69 (18.2\%) students in government medical college were of the opinion that a doctor can refuse to perform abortion even if law allows it as compared to 57 (15.0\%) in private medical college $(\mathrm{p}=0.019)$. Moreover, 80 (21.1\%) students in government medical college strongly disagreed that a patient who wishes to die should be assisted in doing so, as compared to $45(11.8 \%)$ in private medical college $(\mathrm{p}<0.001)$.

Conclusion: Students had knowledge and were aware of the importance of ethics in their profession. The ones belonging to government medical college held stronger views regarding ethical scenarios as compared to the ones in private medical college.
\end{abstract}

Keywords: knowledge, medical ethics, abortion, euthanasia

\section{INTRODUCTION}

Medical ethics is the professional competency of moral issues in medical treatment, healthcare system and research. The importance of ethics education in medical curriculum is increasing (Neitzke, 2008). According to the World Medical Association (WMA) resolution, medical ethics and humans right should be made compulsory and analyzed as part of curriculum in medical school, post graduate medical education and also continuing professional development (2017).

As per previous study, Caribbean physicians have proper training in healthcare ethics (Hariharan et al., 2006). However, a study conducted in India showed lack of medical ethics among medical and dental postgraduates (Janakiram and Gardens, 2014). A study conducted in Lahore, Pakistan concluded that there is lack of healthcare ethics and recommended doctors to attain formal education about medical ethics (Humayun et al., 2008). Another study done to evaluate knowledge, attitude and practice of bioethics among interns and residents in different provinces of Pakistan showed that more than $75 \%$ of senior doctors have unethical etiquette towards junior doctors and patients. Also, $57 \%$ of respondents had lack of knowledge about code of ethics of Pakistan Medical and Dental Council (Imran et al., 2014). Furthermore, it has been identified that junior doctors face ethical dilemma in their newly entered professional life due to lack of training in medical colleges and it has been recommended to have knowledge regarding ethics in their medical years (Imran et al., 2015).

Professionalism, competency and moral qualities can be enhanced by ethics teachings (Chatterjee and Sarkar, 2012). Medical students must view ethics with regard to mandatory and statutory regulations that can protect patients as well as doctors (Arun Babu et al., 2013). Numerous studies have been conducted worldwide to assess the knowledge and practice of medical ethics among undergraduate medical students (Arun Babu et al., 2013; Chatterjee and Sarkar, 2012; Nepal et al., 
Table 1. Demographic details and knowledge regarding ethics among study participants $(n=380)$

\begin{tabular}{|c|c|c|}
\hline \multicolumn{2}{|c|}{ Variable } & n (\%) \\
\hline \multirow{2}{*}{ Gender } & Male & 79 (20.8\%) \\
\hline & Female & $301(79.2 \%)$ \\
\hline \multirow{2}{*}{$\begin{array}{c}\text { Age (Mean } \pm \text { SD) } \\
(21.2 \pm 1.4)\end{array}$} & $18-20$ & 139 (36.6\%) \\
\hline & $21-24$ & $241(63.4 \%)$ \\
\hline \multirow{5}{*}{ Year of study } & First year & $40(10.5 \%)$ \\
\hline & Second year & $87(22.9 \%)$ \\
\hline & Third year & $85(22.4 \%)$ \\
\hline & Fourth year & $79(20.8 \%)$ \\
\hline & Final year & $89(23.4 \%)$ \\
\hline \multirow{4}{*}{$\begin{array}{c}\text { Importance of } \\
\text { ethical } \\
\text { knowledge in } \\
\text { medicine }\end{array}$} & Not at all & $2(5 \%)$ \\
\hline & Somewhat important & $7(1.8 \%)$ \\
\hline & Important & $48(12.6 \%)$ \\
\hline & Very Important & $323(85 \%)$ \\
\hline
\end{tabular}

\begin{tabular}{ccc}
\hline Variable & \multicolumn{2}{c}{$\mathbf{n ~ ( \% )}$} \\
\hline \multirow{2}{*}{ Knowledge of Hippocratic Oath } & Yes & $187(49.2 \%)$ \\
\cline { 2 - 3 } & No & $193(50.8 \%)$ \\
\hline \multirow{2}{*}{ Knowledge of Nurses Code } & Yes & $23(6.1 \%)$ \\
\cline { 2 - 3 } & No & $357(93.9 \%)$ \\
\hline \multirow{2}{*}{ Knowledge of Nuremberg Code } & Yes & $28(7.4 \%)$ \\
\cline { 2 - 3 } & No & $352(92.6 \%)$ \\
\hline \multirow{2}{*}{ Knowledge of Helsinki Declaration } & Yes & $46(12.1 \%)$ \\
\cline { 2 - 3 } & No & $334(87.9 \%)$ \\
\hline \multirow{2}{*}{$\begin{array}{c}\text { Presence of ethical committee at } \\
\text { their college }\end{array}$} & Yes & $69(18.2 \%)$ \\
\cline { 2 - 3 } & No & $140(36.8 \%)$ \\
\cline { 2 - 3 } & Not sure & $171(45.0 \%)$ \\
\hline
\end{tabular}

2017; Okoye et al., 2017). However, no research has been conducted among undergraduate medical students in Pakistan, particularly Karachi to assess the knowledge of medical ethics.

This study aims to assess and compare the knowledge of undergraduate medical students about medical ethics studying in a government and private medical college of Karachi. Students from both types of colleges were taken as it was hypothesized that there can be different institutional factors which can influence knowledge. The results of this study will assist medical colleges in Karachi to enhance the conventional teaching methodology and cultivate the importance of ethics among medical students especially when dealing with real life cases.

\section{METHODS}

A cross-sectional study was conducted between November to December 2019 among medical students at a government medical college and a private medical college after getting formal ethical clearance.

Male and female medical students studying in both selected medical colleges were inducted through non probability convenience sampling after getting their informed consent.

Sample size was estimated from the software Open Epi. With a $34.8 \%$ prevalence of undergraduate medical students' knowledge and $35.7 \%$ prevalence of students' self-acquired knowledge of medical ethics, 95\% confidence level and 5\% bound on error, the estimated sample size came out to be 358 (Chatterjee and Sarkar, 2012, Okoye et al., 2017). With 10\% inflation for non-response, 380 medical students were inducted in the study. The sample size was divided in half for equal representation from both medical colleges.

Medical ethics was defined as "the analytical activity in which the concepts, assumptions, beliefs, attitudes, emotions, reasons and arguments underlying medico-moral decision making are examined critically” (Macnair, 1999).

A structured questionnaire was developed based on scientific literature (Adhikari et al., 2016; Brogen et al., 2009; Hariharan et al., 2006). This tool was used to assess the knowledge of medical students regarding medical ethics and questions related to ethical scenarios faced by doctors. The

questionnaire also contained sociodemographic details along with questions on scenarios relating to ethical issues and sources for gaining knowledge regarding ethics.

The ethical issues question was assessed on a Likert scale of 1 to 5 , with 1 assigned as 'strongly disagree' to 5 assigned as 'strongly agree'. Questionnaire was initially pre-tested to ensure validity. Medical students were approached in their college during their study breaks in college compounds. The self-administered questionnaire was distributed among the consenting students and was collected after they filled it out. Cronbach's alpha of 0.641 revealed a reasonably fair internal consistency with our study population as well.

Data was entered in SPSS version 22, where categorical variables were summarized by frequencies and percentages. Chi Square test was used to find the significant difference between knowledge related to medical ethics between students enrolled in both types of medical college. A p-value of $\leqslant 0.05$ indicated statistical significance.

\section{RESULTS}

Out of 380 students, 301 (79.2\%) were female while 79 (20.8\%) were male with mean age $21.2 \pm 1.4$ years. Majority of the students, i.e., 241 (63.4\%) belonged to 21-24 age group. There were almost equal number of students from 2 nd year onwards with majority of them 323 (85\%) regarded that ethical knowledge in medicine is important. Almost half 187 (49.2\%) had knowledge regarding Hippocratic Oath. However, adequate knowledge regarding Nurses Code, Nuremberg Code and Helsinki Declaration was not known by 357 (93.9 \%), 352 (92.6\%) \& 334 (87.9\%) students respectively. Almost half of the students, 171 (45\%) were not sure about the presence of an ethical committee at their institutes (Table 1).

Comparison was done between knowledge regarding ethical scenarios among government and private medical students' showed no difference between most variables. However, 69 (18.2\%) students in government medical college were of the opinion that doctor can refuse to perform abortion even if law allows it as compared to 57 (15.0\%) in private medical college $(\mathrm{p}=0.019)$. Moreover, there was a significant difference between 80 (21.1\%) government students who strongly disagreed that if a patient who wishes to die should be 
Table 2. Difference of knowledge related to ethical scenarios among students enrolled in government and private medical college $(\mathrm{n}=380)$

\begin{tabular}{|c|c|c|c|c|c|c|}
\hline Variables & $\begin{array}{l}\text { Strongly } \\
\text { disagree } \\
\mathbf{n}(\%)\end{array}$ & $\begin{array}{l}\text { Disagree } \\
\text { n (\%) }\end{array}$ & $\begin{array}{l}\text { Not sure } \\
\text { n (\%) }\end{array}$ & $\begin{array}{l}\text { Agree } \\
\text { n (\%) }\end{array}$ & $\begin{array}{l}\text { Strongly } \\
\text { agree } \\
\text { n (\%) }\end{array}$ & p-value* \\
\hline \multicolumn{7}{|c|}{$\begin{array}{l}\text { 'Ethical conduct is only important to avoid } \\
\text { legal action' }\end{array}$} \\
\hline Government & $32(8.4 \%)$ & $76(20 \%)$ & $40(10.5 \%)$ & $31(8.2 \%)$ & $11(2.9 \%)$ & \\
\hline Private & $23(6.1 \%)$ & $72(18.9 \%)$ & $53(13.9 \%)$ & $32(8.4 \%)$ & $10(2.6 \%)$ & 0.484 \\
\hline \multicolumn{7}{|c|}{$\begin{array}{l}\text { 'The patient should always be told if } \\
\text { something is wrong' }\end{array}$} \\
\hline Government & $4(1.1 \%)$ & $23(6.1 \%)$ & $21(5.5 \%)$ & $88(23.2 \%)$ & $54(14.2 \%)$ & \\
\hline $\begin{array}{r}\text { Private } \\
\end{array}$ & $12(3.2 \%)$ & $22(5.8 \%)$ & $22(5.8 \%)$ & $84(22.1 \%)$ & $50(13.2 \%)$ & 0.368 \\
\hline \multicolumn{7}{|c|}{$\begin{array}{l}\text { 'Patients only need to consent for operations } \\
\text { but not for tests or medications' }\end{array}$} \\
\hline Government & $62(16.3 \%)$ & $86(22.6 \%)$ & $20(5.3 \%)$ & $16(4.2 \%)$ & $6(1.6 \%)$ & \\
\hline $\begin{array}{r}\text { Private } \\
\end{array}$ & $47(12.4 \%)$ & $84(22.1 \%)$ & $25(6.6 \%)$ & $29(7.6 \%)$ & $5(1.3 \%)$ & 0.165 \\
\hline \multicolumn{7}{|c|}{$\begin{array}{l}\text { 'Children (except in an emergency) should } \\
\text { never be treated without the consent of their } \\
\text { parents or guardians' }\end{array}$} \\
\hline Government & $7(1.8 \%)$ & $17(4.5 \%)$ & $18(4.7 \%)$ & $84(22.1 \%)$ & $64(16.8 \%)$ & \\
\hline $\begin{array}{l}\text { Private } \\
\end{array}$ & $7(1.8 \%)$ & $25(6.6 \%)$ & $17(4.5 \%)$ & $95(25.0 \%)$ & $46(12.1 \%)$ & 0.270 \\
\hline \multicolumn{7}{|c|}{$\begin{array}{l}\text { 'Doctors and nurses should refuse to treat } \\
\text { patients who behave violently' }\end{array}$} \\
\hline Government & $32(8.4 \%)$ & $89(23.4 \%)$ & $39(10.3 \%)$ & $18(4.7 \%)$ & $12(3.2 \%)$ & \\
\hline Private & $33(8.7 \%)$ & $72(18.9 \%)$ & $43(11.3 \%)$ & $35(9.2 \%)$ & $7(1.8 \%)$ & 0.067 \\
\hline \multicolumn{7}{|c|}{$\begin{array}{l}\text { The law allows abortion to be performed; } \\
\text { therefore, a doctor cannot refuse to do an } \\
\text { abortion' }\end{array}$} \\
\hline Government & $33(8.7 \%)$ & $69(18.2 \%)$ & $54(14.2 \%)$ & $27(7.1 \%)$ & $7(1.8 \%)$ & \\
\hline Private & $22(5.8 \%)$ & $57(15.0 \%)$ & $49(12.9 \%)$ & $48(12.6 \%)$ & $14(3.7 \%)$ & 0.019 \\
\hline \multicolumn{7}{|c|}{$\begin{array}{l}\text { 'A patient who wishes to die should be } \\
\text { assisted in doing so (euthanasia)' }\end{array}$} \\
\hline Government & $80(21.1 \%)$ & $70(18.4 \%)$ & $27(17.1 \%)$ & $9(2.4 \%)$ & $4(1.1 \%)$ & \\
\hline Private & $45(11.8 \%)$ & $68(17.9 \%)$ & $43(11.3 \%)$ & $22(5.8 \%)$ & $12(3.2 \%)$ & $<0.001$ \\
\hline \multicolumn{7}{|c|}{$\begin{array}{l}\text { 'A patient who refuses to be treated on } \\
\text { religious grounds should be told that they } \\
\text { need to find another doctor with their } \\
\text { beliefs or accept the treatment offered' }\end{array}$} \\
\hline Government & $17(4.5 \%)$ & $49(12.9 \%)$ & $52(13.7 \%)$ & $63(16.6 \%)$ & $9(2.4 \%)$ & \\
\hline Private & $12(3.2 \%)$ & $44(11.6 \%)$ & $55(14.5 \%)$ & $60(15.8 \%)$ & $19(5.0 \%)$ & 0.302 \\
\hline
\end{tabular}

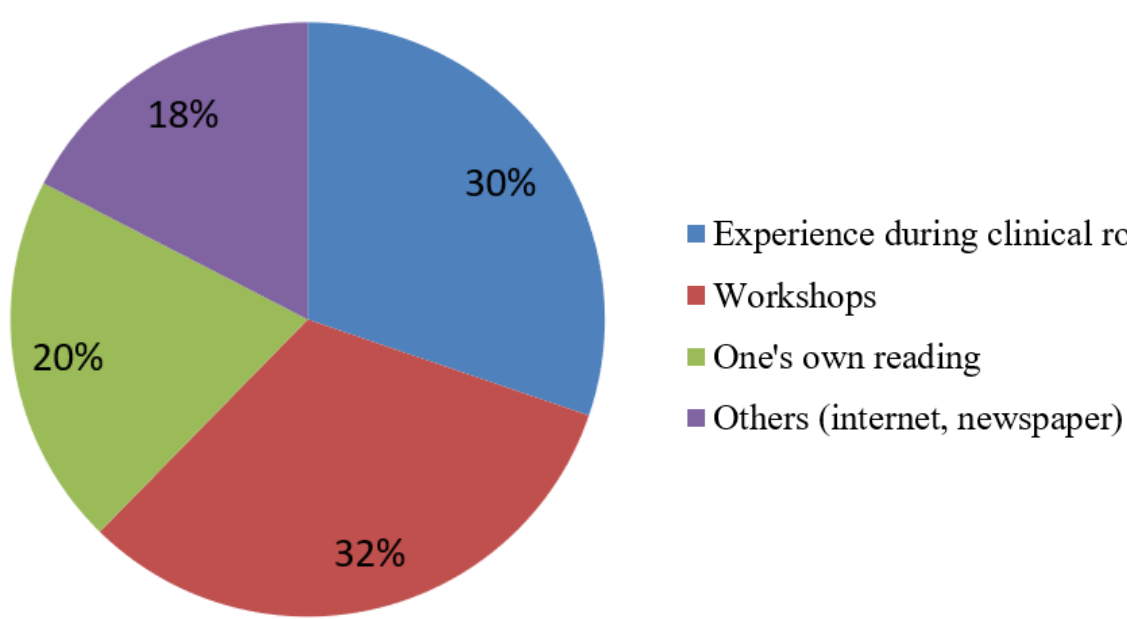

Figure 1. Sources of knowledge for medical ethics $(n=380)$

assisted in doing so as compared to $45(11.8 \%)$ students enrolled in private medical college. $(\mathrm{p}<0.001)$ (Table 2).
Upon enquiring their source of medical ethics knowledge, students reported gaining maximum knowledge from workshops (32\%) (Figure 1). 


\section{DISCUSSION}

Our study focused on medical ethics which should be considered an important part of medical curriculum. Most of the students (85\%) concurred to the importance of medical ethics in the field of medicine. This finding is in line with several studies carried out among doctors and medical students, who agreed to the importance of incorporation of medical ethics teaching at undergraduate level (Adhikari et al., 2016; Okoye et al., 2017; Saied, 2013). However, only 5\% of students considered the knowledge of ethics as unimportant. Similar result was found in a study focusing on surgical team members of Karachi, where $3.96 \%$ of surgeons thought that including medical ethics at undergraduate level was unnecessary (Shiraz et al., 2005).

Furthermore, in our study students got their knowledge of ethics from multiple sources. Majority of them gained their knowledge pertaining to ethics through workshops. Undergraduate medical students in West Bengal and West Indies used similar source to learn about ethics (Chatterjee and Sarkar, 2012, Walrond et al., 2006). However, some of them reported acquiring their knowledge of ethics during clinical rotations. This shows the strong impact of teaching during clinical rotations and observation of physicians during outpatient department and wards on students' knowledge of ethics. A study conducted in Barbados by Hariharan et al shows that experience at work and lectures are significant sources to acquire knowledge of ethics among physicians and nurses (Hariharan et al., 2006).

Unfortunately, in Pakistan, doctors come across cases of ethical dilemmas and ethical misconduct in initial years of their training. Impolite conduct of senior physicians towards medical students, junior doctors and patients is a common practice. Such observations have harmful effects on medical students because they then follow similar attitude in their professional life (Imran et al., 2014). Moreover, majority of students' knowledge regarding laws of ethics was lacking. Very few students were familiar with Nuremberg code and Helsinki declaration. This is evident that students' knowledge of ethical codes was deficient (Janakiram and Gardens, 2014).

A small proportion of students were aware of ethics committee in their institution. However, majority of them were 'not sure' about the role of ethics committee. Similar finding was seen in a study conducted in Barbados (Hariharan et al., 2006). This accentuates the need of ethics committee to publish reports that includes the health related activities organized by them in university and hospital. In addition, these reports should be distributed among students to create awareness (Imran et al., 2014).

In our study, students from government medical college did not support the practice of abortion by doctors even if law allows it. This was congruent to a study conducted in Karachi, which compared knowledge, attitudes and perceptions about induced abortion among medical and nonmedical students. The study revealed that students were not in favor of abortion because extra and premarital affairs and rape was considered most frequent cause of induced abortion (Kumar et al., 2002).

There was a significant difference in opinion about the practice of euthanasia among medical students of both colleges, with students of government medical college not in favor of it. Muslims have a strong belief that remorse and tribulation cannot undo the sin of suicide or mercy killing (Kumar et al., 2017). Similar difference in practice was seen in two public sector teaching hospital in different province of Pakistan where $69 \%$ interns, $67 \%$ junior residents and $51.2 \%$ of senior residents opposed the implementation of euthanasia in clinical practice. The variation in viewpoint could be due to regional and societal differences (Imran et al., 2014). In developed country, like Canada, physicians have low intention to practice physician-assisted suicide in palliative care, even if the law allows them to do so (Lavoie et al., 2015).

Our study highlighted the importance of undergraduate medical students' views regarding ethics. However, there are some limitations in our study. Firstly, our study included one government and one private medical college students, therefore the results cannot be generalized to the medical students of the country. In addition, since it was a cross sectional study, therefore, we cannot report the changes in the knowledge of medical students in future. Furthermore, students enrolled were from all five years whereby ethics knowledge is more focused once clinical rotations start, hence some element of sampling bias cannot be ruled out.

\section{CONCLUSION}

We found that medical students are aware of the importance of medical ethics. Furthermore, students studying in government medical college held stronger views regarding ethical situations concerning abortion and euthanasia. We recommend incorporating ethics as part of medical curriculum to improve the professional conduct of our students.

Author contributions: ZA proposed the study design and conceptualized the project; RF wrote the introduction \& discussion; RS \& MF wrote the results. All authors checked and approved the final manuscript.

Funding: No external funding is received for this article.

Declaration of interest: The authors declare that they have no competing interests.

Ethics approval and consent to participate: Not applicable.

Availability of data and materials: All data generated or analyzed during this study are available for sharing when appropriate request is directed to corresponding author.

\section{REFERENCES}

2017 WMA Resolution on the Inclusion of Medical Ethics and Human Rights in the Curriculum of Medical Schools WorldWide [Online]. World Medical Association. Available at: https://www.wma.net/policies-post/wma-resolution-onthe-inclusion-of-medical-ethics-and-human-rights-inthe-curriculum-of-medical-schools-world-wide/

[Accessed: 19 May 2019].

Adhikari, S., Paudel, K., Aro, A. R., Adhikari, T. B., Adhikari, B. and Mishra, S. R. (2016). Knowledge, attitude and practice of healthcare ethics among resident doctors and ward nurses from a resource poor setting, Nepal. BMC Medical Ethics, 17, 68. https://doi.org/10.1186/s12910-016-0154-9 
Arun Babu, T., Venkatesh, C. and Sharmila, V. (2013). Are tomorrow's doctors aware of the code of medical ethics? Indian J Med Ethics, 10, 192-194. https://doi.org/10.20529/ IJME.2013.056

Brogen, A. S., Rajkumari, B., Laishram, J. and Joy, A. (2009). Knowledge and attitudes of doctors on medical ethics in a teaching hospital, Manipur. Indian J Med Eth, 6, 194-197. https://doi.org/10.20529/IJME.2009.066

Chatterjee, B. and Sarkar, J. (2012). Awareness of medical ethics among undergraduates in a West Bengal medical college. Indian J Med Ethics, 9, 93-100. https://doi.org/10.20529/IJME.2012.029

Hariharan, S., Jonnalagadda, R., Walrond, E. and Moseley, H. (2006). Knowledge, attitudes and practice of healthcare ethics and law among doctors and nurses in Barbados. BMC Med Ethics, 7, E7. https://doi.org/10.1186/1472-6939-7-7

Humayun, A., Fatima, N., Naqqash, S., Hussain, S., Rasheed, A., Imtiaz, H. and Imam, S. Z. (2008). Patients' perception and actual practice of informed consent, privacy and confidentiality in general medical outpatient departments of two tertiary care hospitals of Lahore. BMC Med Ethics, 9, 14. https://doi.org/10.1186/1472-6939-9-14

Imran, N., Haider, I. I., Jawaid, M. and Mazhar, N. (2015). Health ethics education: Knowledge, attitudes and practice of healthcare ethics among interns and residents in Pakistan. J Postgrad Med Ins, 28(4), 383-389.

Janakiram, C. and Gardens, S. J. (2014). Knowledge, attitudes and practices related to healthcare ethics among medical and dental postgraduate students in south India. Indian $J$ Med Ethics, 11, 99-104. https://doi.org/10.20529/ IJME.2014.025

Kumar, A., Naqvi, S., Giyanwani, P. R., Yousuf, F., Masnoon, A., Bai, K. and Kumar, D. (2017). Euthanasia: A Controversial Entity Among Students of Karachi. Cureus, 9.
Kumar, R., Malik, S., Qureshi, A., Khurram, I. M., Chaudhary, K. S., Paul, L., Malik, M. Z., Mahmud, M. K. and Israr, S. M. (2002). Comparative analysis of knowledge, attitudes and perceptions about induced abortions among medical and non-medical students of Karachi. J Pak Med Assoc, 52, 4924. https://doi.org/10.7759/cureus.1510

Lavoie, M., Godin, G., Vezina-Im, L. A., Blondeau, D., Martineau, I. and Roy, L. (2015). Psychosocial determinants of physicians' intention to practice euthanasia in palliative care. BMC Med Ethics, 16, 6. https://doi.org/10.1186/1472-6939-16-6

Macnair, T. (1999). Medical ethics. BMJ, 319, S2-7214. https://doi.org/10.1136/bmj.319.7214.2

Neitzke, G. (2008). [Ethics in medical education]. Bundesgesundheitsblatt Gesundheitsforschung Gesundheitsschutz, 51, 872-879. https://doi.org/10.1007/ s00103-008-0608-4

Nepal, S., Atreya, A. and Kanchan, T. (2017). Awareness and Perceptions of Medical Students towards Health Care Ethics - A Study from Nepal. Kathmandu Univ Med J (KUMJ), $15,313-318$.

Okoye, O., Nwachukwu, D. and Maduka-Okafor, F. C. (2017). Must we remain blind to undergraduate medical ethics education in Africa? A cross-sectional study of Nigerian medical students. BMC Med Ethics, 18, 73. https://doi.org/10.1186/s12910-017-0229-2

Saied, N. H. (2013). Medical students' attitudes to medical ethics education. Annals of the College of Medicine Mosul, 39, 101-106. https://doi.org/10.33899/mmed.2013.81302

Shiraz, B., Shamim, M. S. and Ahmed, A. (2005). Medical ethics in surgical wards: Knowledge, attitude and practice of surgical team members in Karachi. Indian J Med Ethics, 2, 94-96. https://doi.org/10.20529/IJME.2005.048

Walrond, E. R., Jonnalagadda, R., Hariharan, S. and Moseley, H. S. (2006). Knowledge, attitudes and practice of medical students at the Cave Hill Campus in relation to ethics and law in healthcare. West Indian Med J, 55, 42-47. https://doi.org/10.1590/S0043-31442006000100010 